\title{
Measurement of Atmospheric Black Carbon Concentration in Rural and Urban Environments: Cases of Lamto and Abidjan
}

\author{
Adjon A. Kouassi ${ }^{*}{ }^{(0)}$, Madina Doumbia2 ${ }^{\circledR}$, Siélé Silue ${ }^{2}$ (), Eric M. Yao¹, Alima Dajuma², \\ Marcellin Adon ${ }^{3}$ (1), N'datchoh E. Touré ${ }^{3}$ (D), Véronique Yoboue ${ }^{3}$ \\ ${ }^{1}$ Laboratory of Environmental Sciences and Technology (LSTE), Jean Lorougnon Guede University, Daloa, Côte d'Ivoire \\ ${ }^{2}$ Peleforo Gon Coulibaly University, Korhogo, Côte d'Ivoire \\ ${ }^{3}$ Laboratory of Matter Sciences, Environment and Solar Energy (LASMES), Félix Houphouët-Boigny University, Abidjan, \\ Côte d'Ivoire \\ Email: ^adjonkouassi@gmail.com
}

How to cite this paper: Kouassi, A.A. Doumbia, M., Silue, S., Yao, E.M., Dajuma, A., Adon, M., Touré, N.E. and Yoboue, V. (2021) Measurement of Atmospheric Black Carbon Concentration in Rural and Urban Environments: Cases of Lamto and Abidjan. Journal of Environmental Protection, 12, 855-872.

https://doi.org/10.4236/jep.2021.1211050

Received: September 2, 2021

Accepted: October 14, 2021

Published: Novembre 15, 2021

Copyright $\odot 2021$ by author(s) and Scientific Research Publishing Inc. This work is licensed under the Creative Commons Attribution International License (CC BY 4.0).

http://creativecommons.org/licenses/by/4.0/

\begin{abstract}
Black carbon is one of the primary aerosols directly emitted from biomass known to have strong absorbing properties. The INDAAF and PASMU observational field campaigns which took place (2018) in Abidjan (urban area) and Lamto (rural area) allow the analysis of Black carbon concentration at different time scales through real-time measurements using an analyzer named Aethalometer AE-33. Results presented here show at Lamto: 1) for the diurnal scale an average of $1.71 \pm 0.3 \mu \mathrm{g} \cdot \mathrm{m}^{-3}\left(0.34 \pm 0.09 \mu \mathrm{g} \cdot \mathrm{m}^{-3}\right)$ in the dry (wet) season; 2) for the monthly scale an average of $1.14 \pm 0.84 \mu \mathrm{g} \cdot \mathrm{m}^{-3}$; 3 ) on the seasonal scale, an average of $2.2 \pm 0.02 \mu \mathrm{g} \cdot \mathrm{m}^{-3}\left(0.6 \pm 0.19 \mu \mathrm{g} \cdot \mathrm{m}^{-3}\right)$ in the dry (wet) season. The black carbon variation at Lamto is seasonal with an amplification factor of 85.6. Regarding the urban area of Abidjan, due to sampling issues, our analyses were limited to daily, diurnal and weekly time scales. We observed: a) at a daily scale an average of $5.31 . \pm 2.5 \mu \mathrm{g} \cdot \mathrm{m}^{-3}, \mathrm{~b}$ ) diurnal scale, an average ranging from 6.87 to $13.92 \mu \mathrm{g} \cdot \mathrm{m}^{-3}$. The analysis indicated that emissions from urban areas are more related to social and economic activities, with weekday concentrations $\left(7.24 \mu \mathrm{g} \cdot \mathrm{m}^{-3}\right)$ higher than concentrations over the weekend (e.g. Saturday $6.59 \mu \mathrm{g} \cdot \mathrm{m}^{-3}$ and Sunday 6.00 $\left.\mu \mathrm{g} \cdot \mathrm{m}^{-3}\right)$. Moreover, $\mathrm{BC}$ concentration in Abidjan is quite noticeable compared to that of rural areas (Lamto). The ratio between the maximum values of the two areas is of the order of 5.86. In addition, concentrations in some urban areas are slightly above the daily threshold set by the WHO $\left(10 \mu \mathrm{g} \cdot \mathrm{m}^{-3}\right)$. Therefore, the levels of urban $\mathrm{BC}$ concentrations are alarming whilst rural $\mathrm{BC}$ concentrations remain below daily WHO thresholds and are of the same magnitude as those of West African megacities. This study underlies that BC
\end{abstract}


concentrations at Lamto are mainly related to biomass combustion sources while those from urban areas are related to traffic sources. The latter is permanently active, unlike those in rural Lamto, which is seasonal.

\section{Keywords}

Carbonaceous Aerosols, Black Carbon, Source Apportionment, Fossil Fuel, Biomass Burning

\section{Introduction}

Black carbon (BC), is a component of atmospheric particulate matter (PM) and is described as a solid pure carbon material formed during combustion. It is emitted during the incomplete combustion of fossil fuels, and biomass burning [1] and absorbs at all wavelengths of solar radiation [2]. It is usually co-emitted with other organic matter. The interest in Black carbon comes from its climatic, environmental and health implications [3]. Indeed, BC contributes significantly to climate change by absorbing incoming solar radiation and has a strong absorption capacity of short-wave radiation. Thus it increases atmospheric warming, alters atmospheric stability and affects clouds by modifying the hygroscopicity of cloud condensation nuclei [4]. As far as BC is concerned, it may have a net warming impact, while other aerosols (i.e. nitrates, sulfates, organic carbon, etc.) may have a cooling effect [2]. BC directly influences the global radiation balance, and has a lifetime ranging from 1 week to 10 days in the absence of precipitation and is therefore conducive to long-range transport [5]. BC particles also have adverse health effects [6]. The very small size of BC (PM 2.5) allows access to the finest lung branches (alveoli). Though uncertainties remain on the toxicity of the graphitized carbon core, it serves as a vector for organic and metallic compounds that have proven health effects [7].

Globally, about $20 \%$ of black carbon is emitted from the combustion of biofuels, $40 \%$ from fossil fuels and $40 \%$ from open-burning biomass [8]. It is therefore essential to study the characteristics of black carbon, in order to evaluate its radiative properties and quantify its contribution to atmospheric pollution in different regions. For instance, in Africa, urban air pollution is a major issue, especially in regions with high population monitoring atmospheric pollution and air quality remains a priority for the scientific community in the context of environmental preservation in order to implement measures for reducing the emission of atmospheric pollutants. Many studies have analyzed atmospheric BC and its impacts on household air pollution and human health in Asia [9] [10] [11] [12] [13], in Latin America [14] [15] [16] and in Africa [17] [18].

Moreover, airborne measurements were made during the international observation network IDAF in 1994 which is part of the international Global Atmospheric Chemistry Deposition of Biogeochemically Important Trace Species (IGAC-DEBITS-Africa) project. Later in 2016, the IDAF became INDAAF and 
monitors atmospheric composition over Africa on a long-term basis.

In addition, research studies on rainfall chemistry, atmospheric pollutants and deposition fluxes at the scale of African ecosystems have been carried out to this effect ([19] [20] [21] [22]). In collaboration with other programs (POLCA, DACCIWA) experimental studies have been realized in West African capitals cities ([23] [24] [25] [26]). Recently, a program named PASMU (Air Pollution and Health in Urban Environments) was established to study air pollution in two urban areas in Côte d'Ivoire (Abidjan and Korhogo) and its related health impact on health.

This present work is part of the PASMU project (urban area) and the INDAAF network (rural area). It focuses on measurements of BC concentrations carried out using the Aethalometer AE33 (Magee Scientific, USA).

The main purpose of this study is to analyze variations of $\mathrm{BC}$ concentration at different spatio-temporal scale and compare concentration levels between rural and urban sites. Here, aerosol BC content was investigated for two typical regions and measured from 2015 to 2017 in the rural area of Lamto, and the urban area of Abidjan. The latter is growing rapidly towards a megacity. Spatial-temporal variations of BC concentrations were analyzed and discussed as well as their potential sources, which might be are helpful to understand the impact of BC on air quality, human health and climate change.

\section{Methodology}

\subsection{Measurement Sites}

The sites of our study concern one of the INDAAF network measurement site of Lamto (rural area) and one PASMU project site, Abidjan (urban site). The former represents a savannah ecosystem and has one of the most important scientific databases. It is a geophysical station and also a measurement site of the INDAAF network, located at $160 \mathrm{~km}$ north of Abidjan city, which geographical coordinates are: Latitude $6^{\circ} 13^{\prime}$ North, $5^{\circ} 02^{\prime}$ West Longitude $5^{\circ} 02^{\prime}$ West and at altitude of $105 \mathrm{~m}$. The reserve has an area of about 2500 ha. of savannah and gallery forest, along the Bandama River. The region is characterized by four seasons, e.g two dry and two wet seasons [27]. The dry season expends from November to February, while the wet season stretches from March to October. During the wet season, moisture-laden oceanic air masses carry various species of marine aerosols to this rural area [19]. In addition, throughout the dry season, terrigenous particles and various species from combustion processes (savannah fires, open burning) are carried by the Harmattan. The mean annual rainfall amount is about $1212 \mathrm{~mm}$. For instance, the amount of rainfall collected in 2014 and 2007 are respective $991.9 \mathrm{~mm}$ and $1586.2 \mathrm{~mm}$. As Lamto is a geophysical site, several climate parameters are measured, the daily database covers 50 years, from 1962 to 2011.

The second site is Abidjan city, the economic capital of Côte d'Ivoire, located in the south of the country in the Guinean Gulf between $5^{\circ} 00^{\prime}$ and $5^{\circ} 30^{\prime}$ North 
latitude, and $3^{\circ} 50^{\prime}$ and $4^{\circ} 10^{\prime}$ West longitude. It covers an area of approximately 57,735 ha [28]. This city is considered as a cultural crossroads and has experienced rapid economic growth and high immigration in recent years. Its population is estimated at more than 7404 million inhabitants (RGPH, 2014), i.e. $20.8 \%$ of the total population in Côte d'Ivoire (INS, 2015). As a result, Abidjan is facing numerous anthropogenic emissions, due to the galloping demography and rapid urbanization. The area is characterized by a warm and humid sub-equatorial climate, with two alternating rainy and dry seasons. On the West African coasts, there is an alternation of the climatic profile, which is due to the passage of the inter tropical front [29] [30]. As a result, the seasonal climatic profile of Abidjan is a reflection of this alternation. Indeed, the climate is sub-equatorial, and defined by four major seasons: the great dry season (December to March), the great rainy season (April to July); the small dry season, (August to September); the small rainy season (October to November).

\subsection{Measurements and Instrumentation}

The sampling of aerosol Black Carbon PM2.5 mass concentrations is carried out continuously at the Lamto site using the 7 wavelength Aethalometer (model AE-33). The instrument measures the optical attenuation or absorbance of light from LED lamps at seven wavelengths (370, 470, 520, 590, 660, 880 and $950 \mathrm{~nm}$ ) [31] [32]. The principle of black carbon determination assumes that all light absorbing materials are composed of $\mathrm{BC}$. The effective attenuation specific mass, " $A T N$ " of the Aethalometer used for the determination of $\mathrm{BC}$ concentration is $14.625 / \lambda\left(\right.$ in $\left.^{2} \cdot \mathrm{g}^{-1}\right)$, as recommended by the manufacturer. The uncertainty of the Aethalometer indicated by the manufacturer is 5.0\% [33] [34]. To account for the "shadowing" effect due to the filter loading (decrease in the sensitivity of the Aethalometer), a loading correction, " $R$ " ( $A T N)$ was performed [35]. In order to avoid the effect of humidity on the Aethalometer measurements, the aerosol is pre-dried (less than $40 \%$ RRH) by diffusion before detection. Previous studies have shown that some organic aerosols from wood combustion have absorption peaks at wavelengths of $370 \mathrm{~nm}$ compared to $880 \mathrm{~nm}$ [36]. Attenuation coefficients of $15.4,16.6,22.2,24.8,28.1,31.1$, and $39.5 \mathrm{~m}^{2} \cdot \mathrm{g}^{-1}$ were used for the $950,880,660,590,520,470$ and $370 \mathrm{~nm}$ wavelength respectively, as recommended by the manufacturer. Consequently, a difference between BC measured at 370 and $880 \mathrm{~nm}$ channels can provide useful information on potential BC sources, which can be used as a qualitative indicator, especially for wood smoke particles from local wood combustion sources [37] [38]. However, in order to find the total BC concentration, the wavelength of $880 \mathrm{~nm}$ was used in the present study as it has also been used in other studies [39], although, some studies have underlined the need and importance of additional corrections for instrumental artifacts and dust absorption [40].

The data were sampled from January 2015 to May 2017 with a frequency of 30 minutes in the wet season and 10 minutes for the dry season, at the Lamto site. 
Concerning the urban site in Abidjan, the Aethalometer was installed at Cocody, at the University Felix Houphouët Boigny. It is worthy to note that Cocody is a residential area, with some few schools and academic institutions. For Abidjan, the Aethalometer was installed at Cocody on a site of the University Felix Houphouët Boigny. It should be remembered that Cocody is a residential area, with a few schools and academic institutions. The measurement protocol developed allowed us to have a database from July 2018 to January 2020. It is important to mention that some technical problems occurred with the Aethalometer due to sampling conditions, and therefore we have discontinuities in the database.

\section{Results and Discussion}

\subsection{Rural Area}

\subsubsection{BC Diurnal Variations}

$\mathrm{BC}$ diurnal variations were investigated by calculating daily average of $\mathrm{BC}$ concentrations for each month. Figure 1 shows its variation for a daily average of a dry and wet season. The analysis shows that $\mathrm{BC}$ concentrations vary from 1.25 to $2.70 \mu \mathrm{g} \cdot \mathrm{m}^{-3}$, in the dry season (D.S) while they are lower than $0.60 \mu \mathrm{g} \cdot \mathrm{m}^{-3}$ in wet season (W.S). The variation factor is about six times higher than those of wet season. The diurnal $\mathrm{BC}$ concentrations in the dry season show quite noticeable variations. Indeed, from $0 \mathrm{AM}$ to $7 \mathrm{AM}, \mathrm{BC}$ concentrations oscillate around 1.5 $\mu \mathrm{g} \cdot \mathrm{m}^{-3}$. From 7:00 AM onward, the concentration increases to a maximum value of $2.70 \mu \mathrm{g} \cdot \mathrm{m}^{-3}$ around 1:30 $\mathrm{pm}$, followed by a gradual decrease until $9 \mathrm{PM}$ where it reaches $1.5 \mu \mathrm{g} \cdot \mathrm{m}^{-3}$ and stays constant throughout the night so, the diurnal cycle resumes. There is a significant variation in the diurnal evolution which could be related to two situations:
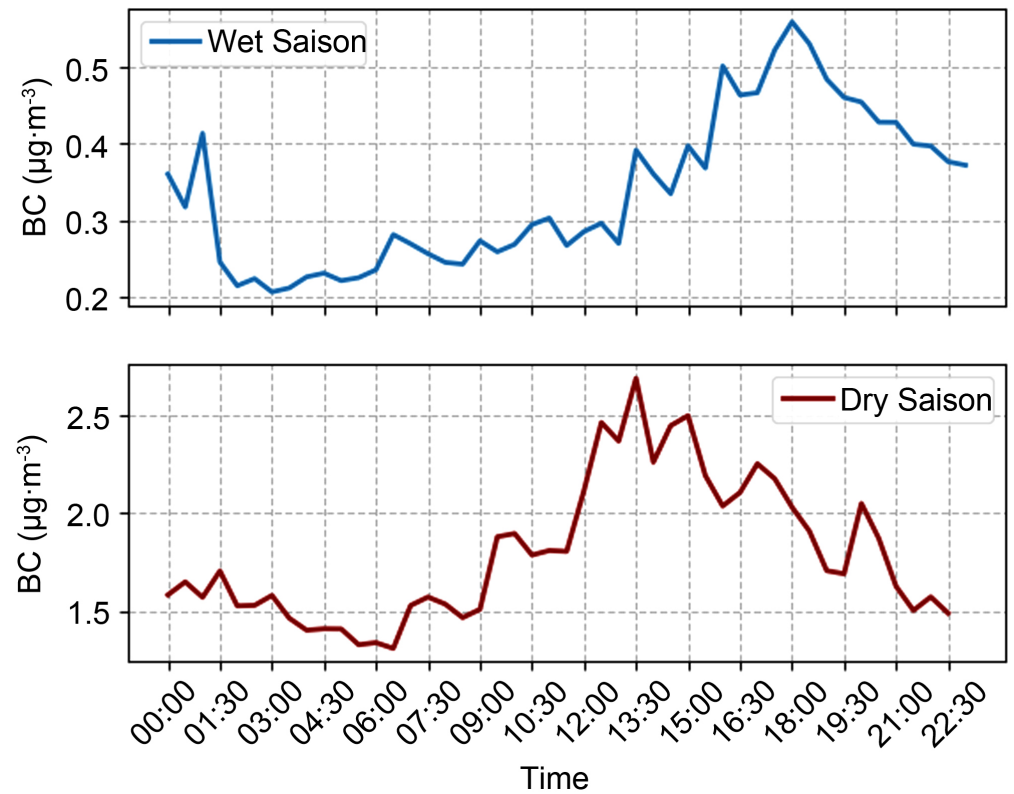

Figure 1. Average daytime concentrations of BC in Lamto DS: dry season, WS: wet season. 
- Local anthropogenic activities linked to agricultural. In fact, the sharp increase of BC concentration starts at 7 AM, until about 2 PM and then decreases until late evening (7 PM). This behavior corresponds to the beginning and end of the daily agricultural activities. The peak concentration observed at 01:30 PM corresponds to the time of setting fire to the agricultural plots. It also coincided with the time of biomass burning and charcoal production activities increase in the areas surrounding the reserve. On one hand, at this particular time, air temperature is at its maximum thus, facilitating the combustion. On the other hand, high air temperature combined with the increase of boundary layer height which induces aerosol particle vertical dispersion. The period from $5 \mathrm{PM}$ to $7 \mathrm{PM}$ matches the time when the fires are extinguished after the farmers have left. Moreover, the peak observed at 8:00 PM could be justified by emissions from domestic activities, such as wood burning (e.g. for cooking purposes), nightly wood fires around the reserve.

- Climatic parameters, indeed, during the dry season, air temperatures are quite high and humidity is low. This leads to frequent emission of BC through processes such as bush fires, wood fires, etc.

During the wet season, aerosol wet deposition occurs frequently, which lead to low atmospheric concentration of $\mathrm{BC}\left(0.5 \mu \mathrm{g} \cdot \mathrm{m}^{-3}\right)$ at all time during the day. Atmospheric variation of $\mathrm{BC}$ concentration during this period remains not meaningful. However, a maximum value of $0.56 \mu \mathrm{g} \cdot \mathrm{m}^{-3}$ is reached around 6:00 PM which could be attributed to domestic activities in the neighboring villages as shown in Table 1.

\subsubsection{Monthly Variations}

The monthly variations of BC concentrations from January 2015 to May 2017, are presented in Figure 2. Nevertheless, discontinuities were observed in the data, for the period of April 2017 and June to December 2017, which is mainly due to maintenance of the Aethalometer. Over the study period, monthly BC concentrations vary from $0.046 \mu \mathrm{g} \cdot \mathrm{m}^{-3}$ (August 2015) to $3.942 \mu \mathrm{g} \cdot \mathrm{m}^{-3}$ (December 2015) with an average of $1.141 \pm 0.84 \mu \mathrm{g} \cdot \mathrm{m}^{-3}$.

At Lamto, the dry season covers the months from November to February and the wet season extends from March to October. BC concentrations decrease from January to March; and then show lowest values from April to September and increase again during dry month from October to December. The highest

Table 1. Diurnal concentration of BC: minimum (Min), maximum (Max) and average (Avg) for dry (DS) and wet (WS) seasons (2016).

\begin{tabular}{ccccc}
\hline \multirow{4}{*}{ Diurnal } & \multicolumn{4}{c}{ BC concentration in $\mu \mathrm{g} \cdot \mathrm{m}^{-3}$} \\
\cline { 2 - 5 } & Min & 1.31 & Min & 0.21 \\
& Max & 2.69 & Max & 0.56 \\
& Avg & $1.79 \pm 0.3$ & Avg & $0.34 \pm 0.09$ \\
\hline
\end{tabular}




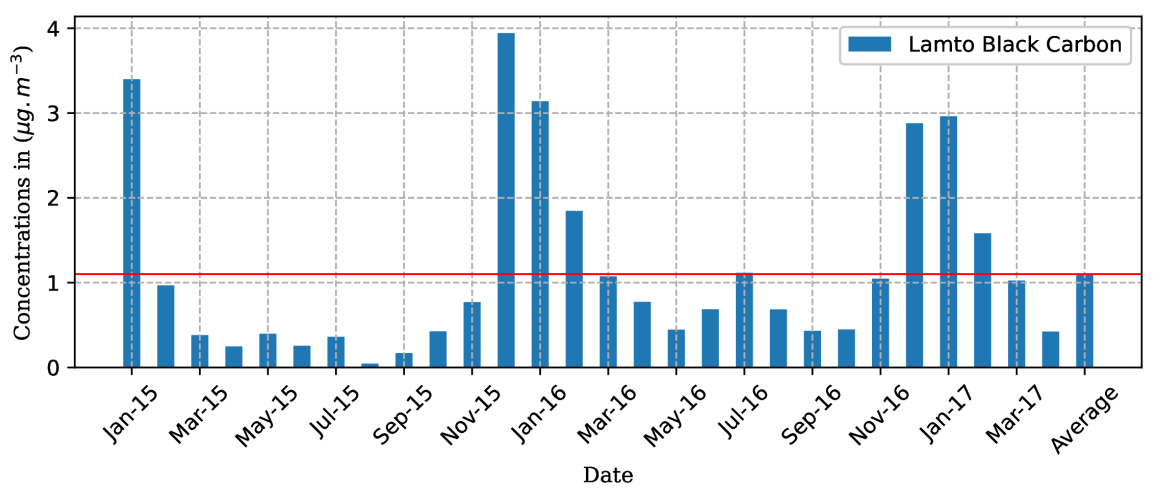

Figure 2. Monthly BC concentrations at Lamto, from 2015 to 2017.

monthly concentration values are recorded during the dry season: the peak value appears in December $2015\left(3.942 \mu \mathrm{g} \cdot \mathrm{m}^{-3}\right)$.

The minimum values are rather obtained during the wet season with value of $0.046 \mu \mathrm{g} \cdot \mathrm{m}^{-3}$ in August 2015. The ratio Max/Min of BC concentrations over this period is 85.6. The variation of $\mathrm{BC}$ concentrations is more pronounced during the dry season, as the monthly peaks are reached at this period of the year (November to February). Figure 3 presents the seasonal cycle of BC concentration in Lamto, from 2015 to 2017 and their average over the period. The annual cycle of $\mathrm{BC}$ is similar from one year to another.

Over the study period, the results obtained indicate maximum values from

November to February corresponding to the peak of BC emitted by biomass burning fires at this period, the lowest values are observed during the wet season (March-October), except for the month of July, which shows a peak. This second peak corresponds to the effect of the little dry season, which is highlighted by an increase of airborne particles. The monthly BC average (2015-2017) pattern is similar for each year from 2015 to 2017.

The minimum values are obtained during the wet season (April-October) and the highest concentrations, during the dry season. The average monthly concentrations in Lamto over the study period range from 0.30 to $3.41 \mu \mathrm{g} \cdot \mathrm{m}^{-3}$ respectively in September and December.

\subsubsection{Seasonal Variations}

The seasonal variations of $\mathrm{BC}$ concentrations over the study period are presented in Figure 4. For the dry season, the $\mathrm{BC}$ concentration levels obtained are almost of the same order of magnitude $2.23 \mu \mathrm{g} \cdot \mathrm{m}^{-3}$ to $2.27 \mu \mathrm{g} \cdot \mathrm{m}^{-3}$ from 2015 to 2017. From January 2015 to May 2017, the average concentration of BC corresponding to the dry season is $2.26 \pm 0.02 \mu \mathrm{g} \cdot \mathrm{m}^{-3}$.

Regarding the wet season, fluctuations over the period are significant from 2015 to 2016. BC concentrations vary from $0.28 \mu \mathrm{g} \cdot \mathrm{m}^{-3}$ in 2015 to $0.72 \mu \mathrm{g} \cdot \mathrm{m}^{-3}$ in 2017 with an average of $0.57 \pm 0.19 \mu \mathrm{g} \cdot \mathrm{m}^{-3}$ over the period of interest. The atmospheric $\mathrm{BC}$ concentration levels at Lamto are higher during the dry season compared to the wet season. One reason could be emissions from biomass fires 


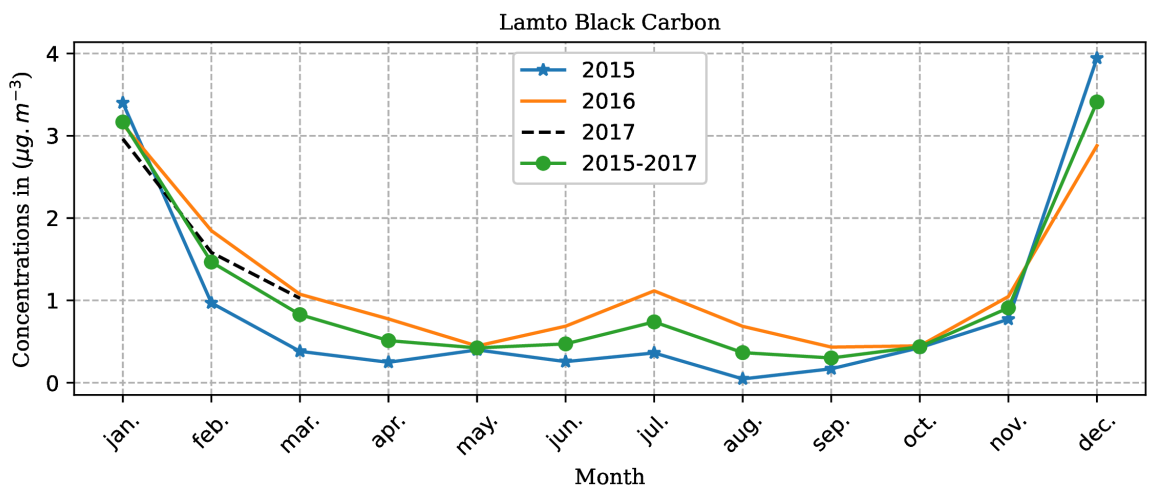

Figure 3. Seasonal cycle of BC concentrations and averaged over the period (2015-2017) in Lamto.

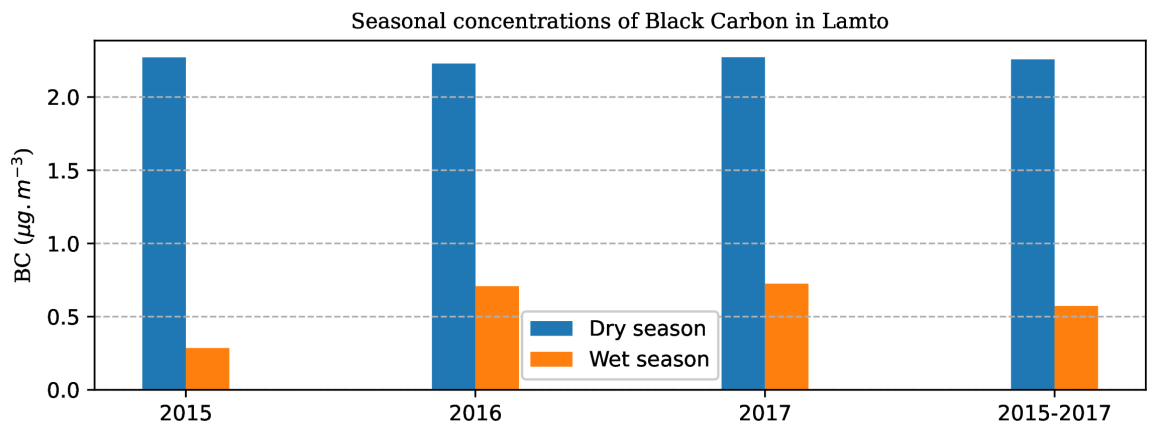

Figure 4. Seasonal BC concentrations in Lamto, from 2015 to 2017.

in this area [41].

Indeed, it is well documented that in humid tropical forest areas, the presence of carbonaceous particles in the atmosphere is generally linked to emissions from biomass fires and domestic fires. In addition, in rural areas, agricultural practices such as shifting cultivation and the preparation of agricultural land through burning are practices linked to human activities. Biomass fires appear important during the dry season, as they allow for the preparation of cultivable land (clearing) before cultivation. "Reference" [42] showed that in the savanna zone about $80 \%$ of the land is burnt during the dry season, thus influencing concentration levels.

Moreover, domestic cooking fires contributes to the release of BC into the atmosphere as they represent the burning of wood and charcoal, which are used as a means of energy production (e.g. cooking, heating, etc.) in neighboring villages around Lamto. During the wet season, BC concentrations are low, e.g. 0.7 $\mu \mathrm{g} \cdot \mathrm{m}^{-3}$ and $0.3 \mu \mathrm{g} \cdot \mathrm{m}^{-3}$ in 2016 , and 2015 respectively. The latter result could be explained by the phenomenon of leaching which induces a substantial deposition of atmospheric particles. The agricultural practices at this period oriented towards sowing and harvesting, rather than burning of fields, could also justify the low concentrations of BC. However, it should be noted that the order of magnitude of BC concentrations in the wet season of 2015 is the lowest compared to others. The justification could be that the rainy season in 2015, was ab- 
undant, or extended compared to years 2016 and 2017 at the Lamto as shown in Table 2.

For Lamto rural area we have an average of $2.2 \mu \mathrm{g} \cdot \mathrm{m}^{-3}$ in the dry season and $0.6 \mu \mathrm{g} \cdot \mathrm{m}^{-3}$ in the wet season, over the study period. These results are similar to those obtained by Ouafo Mendo-Leumbe et al. (2018) [43], 1.7 and $0.8 \mu \mathrm{g} \cdot \mathrm{m}^{-3}$ for the dry and wet seasons respectively during cases studies conducted from 2005 to 2009 in Djougou (Benin). The average BC concentration obtained during the dry season also corroborates with the observed $\mathrm{BC}$ concentration from the FOS-DECAFE campaign in 1991, $\left(1.9 \mu \mathrm{g} \cdot \mathrm{m}^{-3}\right)$, by [44]. Nevertheless, it is worth noting that the values obtained in Lamto are slightly higher than those of Djougou. This confirms the wetter character of the Lamto savannah, compared to Djougou.

\subsection{Urban Area}

\subsubsection{Daily Variations}

Daily variation of $\mathrm{BC}$ concentrations in Abidjan from 01 July 2018 to 27 January 2020, are presented in Figure 5. BC concentrations are ranging from $0.83 \mu \mathrm{g} \cdot \mathrm{m}^{-3}$ (August 2018) to $14.56 \mu \mathrm{g} \cdot \mathrm{m}^{-3}$ in (January 2020), with an average concentration over the period of $5.31 \pm 2.5 \mu \mathrm{g} \cdot \mathrm{m}^{-3}$. The concentrations decrease progressively from July to August $2018\left(14.07 \mu \mathrm{g} \cdot \mathrm{m}^{-3}\right.$ to $\left.0.83 \mu \mathrm{g} \cdot \mathrm{m}^{-3}\right)$ then increase from October to January during dry season. Despite the atmospheric washout induced by the intense rainfall in July, this month shows high concentrations of $\mathrm{BC}$, with peaks of 12 and $14 \mu \mathrm{g} \cdot \mathrm{m}^{-3}$, as in the dry seasons of December and January. This finding implies that atmospheric $\mathrm{BC}$ emissions in urban areas are not governed by seasonality, but rather impacted by anthropogenic sources.

The low concentration values in August are firstly due to a decrease in road traffic during this period which corresponds to school holidays. Secondly, it

Table 2. Annual and seasonal BC concentrations in Lamto (2015-2017): minimum (Min), maximum (Max) and Average (Avg).

\begin{tabular}{|c|c|c|c|c|c|}
\hline & \multicolumn{5}{|c|}{$\mathrm{BC}$ concentration in $\mu \mathrm{g} \cdot \mathrm{m}^{-3}$} \\
\hline & \multicolumn{2}{|c|}{ D.S } & \multicolumn{2}{|c|}{ W.S } & Average \\
\hline \multirow{3}{*}{2015} & Min & 0.77 & Min & 0.04 & \\
\hline & Max & 3.94 & Max & 0.42 & $0.95 \pm 0.18$ \\
\hline & Avg & 2.27 & Avg & 0.28 & \\
\hline \multirow{3}{*}{2016} & Min & 0.4 & Min & 0.43 & \\
\hline & Max & 1.02 & Max & 1.12 & $1.21 \pm 0.77$ \\
\hline & Avg & 0.73 & Avg & 0.73 & \\
\hline \multirow{3}{*}{2017} & Min & 1.56 & Min & 0.4 & \\
\hline & Max & 2.96 & Max & 1.02 & $1.5 \pm 0.77$ \\
\hline & Avg & 2.27 & Avg & 0.73 & \\
\hline \multirow{3}{*}{$2015-2017$} & Min & 2.23 & Min & 0.28 & \\
\hline & Max & 2.27 & Max & 0.73 & $1.2 \pm 0.18$ \\
\hline & Avg & $2.2 \pm 0.02$ & Avg & $0.6 \pm 0.19$ & \\
\hline
\end{tabular}




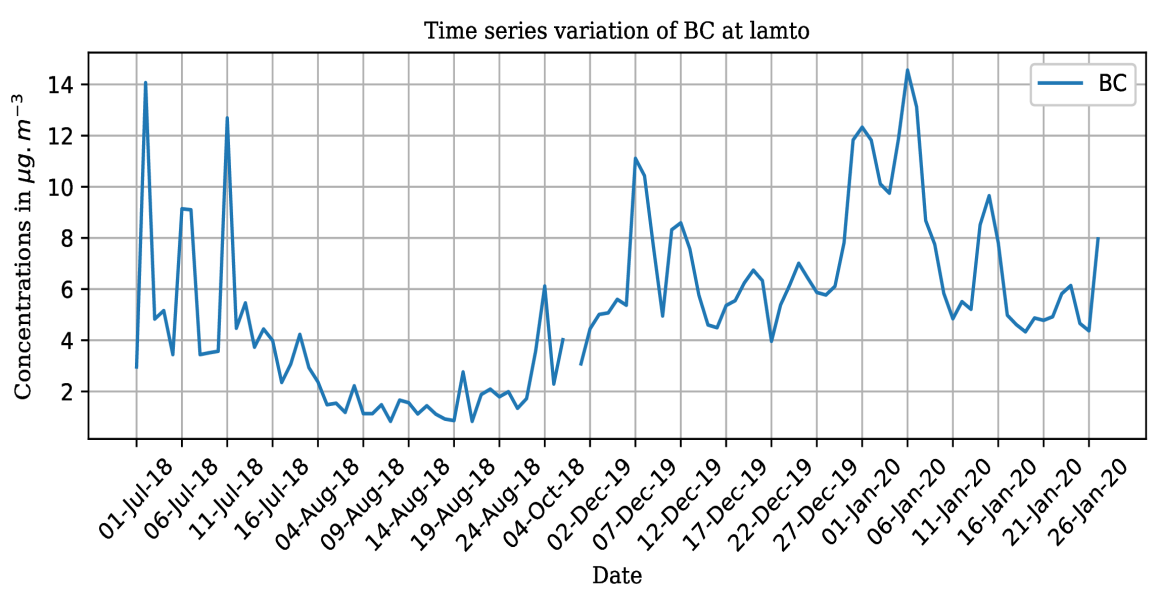

Figure 5. Times series variation of BC concentration at Abidjan from 2018 to 2020.

could be attributed to the low air temperatures experienced by the city of Abidjan during this period. In fact, these low air temperatures are related by the cooler ocean surface temperatures (SST) over the Gulf of Guinea coasts during this period. Indeed, these low temperatures do not favor combustion processes such as the combustion of waste, occurring around the site. However, the relatively high concentration levels in July, observed in the middle of the rainy season, can be justified by fairly high traffic emissions. Obviously, the decrease of $\mathrm{BC}$ concentration level after mid-July could be linked to a decrease in road traffic related to the period of major holidays. Actually, compared to biomass combustion, fossil fuels are the major sources of $\mathrm{BC}$ release during the wet season compare in to the dry season [45].

\subsubsection{Weekly Variations}

High $\mathrm{BC}$ concentrations in urban areas imply that anthropogenic activities are the major source of emissions. In order to justify our hypothesis, we analyzed the diurnal variation of urban $\mathrm{BC}$ concentrations according to days of the week. The diurnal concentrations of $\mathrm{BC}$ were averaged from Monday to Friday in order to distinguish the evolution of daytime concentrations between working days and weekend (e.g. Saturday and Sunday). The idea behind is to highlight that $\mathrm{BC}$ emissions are modulated by socioeconomic activities. The diurnal variation of $\mathrm{BC}$ concentrations on weekdays and weekend is presented in Figure 6. The weekdays are averaged over two months

The analysis showed a rather similar pattern of diurnal BC concentrations for all the weekdays from Monday to Friday, and for Saturday, with the exception of Sunday. During the week, BC concentrations increase progressively in the early morning from 5 to $8 \mathrm{AM}$ with values ranging from 7.11 to $14.00 \mu \mathrm{g} \cdot \mathrm{m}^{-3}$, then decrease until $12 \mathrm{PM}$ to reach values of approximately $5.77 \mu \mathrm{g} \cdot \mathrm{m}^{-3}$, and remain almost constant from this time until 4 PM. Then concentrations rise again until around 9 PM before dropping back to around $5.98 \mu \mathrm{g} \cdot \mathrm{m}^{-3}$ at midnight. The lowest values on weekdays are obtained between noon and 4 PM. This peak observed at 7 AM suggests that there is a correlation between traffic source and $\mathrm{BC}$ 


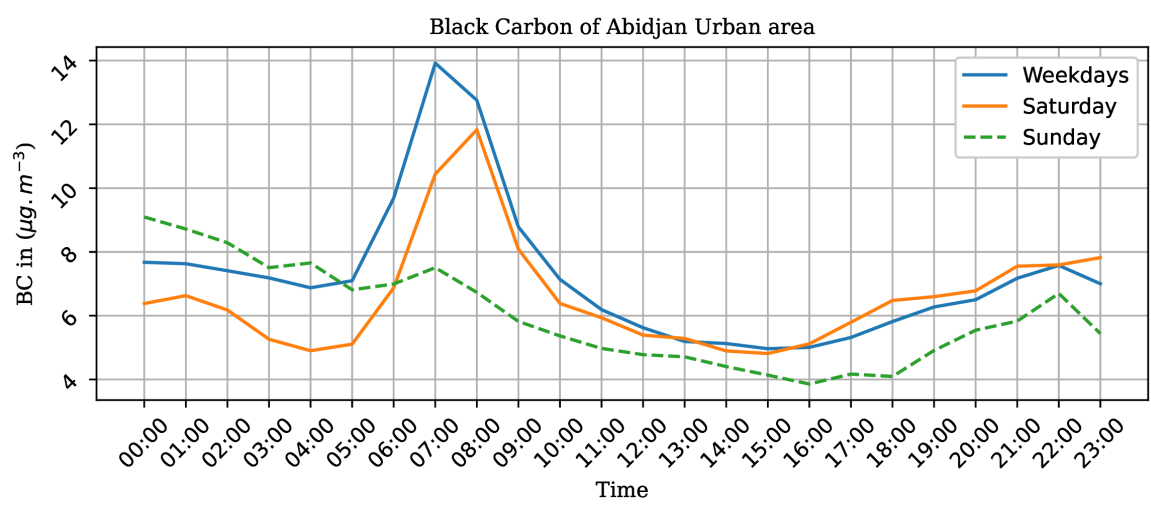

Figure 6. Diurnal concentrations of BC for week-days (Monday to Friday) and weekend, in Abidjan.

emissions.

Indeed, in the early morning, the main traffic source intensifies due to working hours. To addition to this phenom the stability of the boundary layer (low surface temperature in the mornings) prevents the dispersion of BC (local pollution). The increasing concentrations from $4 \mathrm{PM}$ afterwards could be due to the hours during which people return back from works, thus by the return home characterized by heavy road traffic. The high values observed at night (7 - 9 PM) can be attributed to certain factors. Particularly at this time, domestic fire occurs at home for cooking purposes (e.g. a large part of the population uses charcoal for cooking). Traffic sources are also important at night. The concentrations drop from $0 \mathrm{AM}$ to about $4 \mathrm{AM}$, highlighting the end of some emitting activities and a considerable decrease in car road traffic.

We note that the diurnal evolution of BC for Saturday has the same trend as the average for working days (Monday to Friday). There is a time lag between the peaks of $14.00 \mu \mathrm{g} \cdot \mathrm{m}^{-3}$, (at $7 \mathrm{AM}$ ) for the working days, against $12.00 \mu \mathrm{g} \cdot \mathrm{m}^{-3}$, (at 8 AM) Saturday. As far as traffic-related BC emissions is concerned, this could implies that on Saturdays fewer people go out and they dont go out early as on weekdays From 5 PM to 10 PM, BC concentrations on Saturdays (6.60 to $7.90 \mu \mathrm{g} \cdot \mathrm{m}^{-3}$ ) are higher than those observed on weekdays (from 6.00 to 7.58 $\mu \mathrm{g} \cdot \mathrm{m}^{-3}$ ) and Sundays (from 4.90 to $6.69 \mu \mathrm{g} \cdot \mathrm{m}^{-3}$ ).

In fact, there is a weekend effect characterized by the massive outflow of people (road traffic), night-time sales (wood burning, charcoal burning).

The evolution of $\mathrm{BC}$ concentrations on Sundays shows rather low concentration levels and a different pattern (between 5.82 and $7.50 \mu \mathrm{g} \cdot \mathrm{m}^{-3}$ ) compared to those obtained on weekdays (between 8.78 and $13.92 \mu \mathrm{g} \cdot \mathrm{m}^{-3}$ ) and Saturdays (6.98 and $11.83 \mu \mathrm{g} \cdot \mathrm{m}^{-3}$ ). This could be explained by a decrease in work activities during the weekend, which is even more pronounced.

Similar results were found by [45] in the city of Bamako, Table 3 presents comparison between this study and the latter. Indeed the diurnal concentrations of BC during working days and weekends were respectively $30 \mu \mathrm{g} \cdot \mathrm{m}^{-3}$ and 10 $\mu \mathrm{g} \cdot \mathrm{m}^{-3}$, with peak values obtained between $6 \mathrm{AM}$ and 9 AM. Compared to this 
Table 3. Diurnal concentrations of BC for week-days (Monday to Friday) and weekend, in Abidjan.

\begin{tabular}{ccc}
\hline \multirow{2}{*}{ References } & BC concentration & $\left(\mu \mathrm{g} \cdot \mathrm{m}^{-3}\right)$ \\
\cline { 2 - 3 } & Week-day & Weekend \\
\hline Doumbia et al., 2012 [45] & 30 & 10 \\
This study & 13.92 & 11.83 \\
\hline
\end{tabular}

study results obtained on weekends are of the same order of magnitude, whereas the urban $\mathrm{BC}$ concentrations in Bamako during working days are about 2 times higher.

\subsection{Comparison of Rural and Urban Areas}

At Lamto, the variability of diurnal $\mathrm{BC}$ concentrations is rather low during dry season with a maximum concentration of $2.69 \mu \mathrm{g} \cdot \mathrm{m}^{-3}$ (6 PM) and a minimum of $1.31 \mu \mathrm{g} \cdot \mathrm{m}^{-3}$ (6:30 AM). During the wet season, the variability of BC concentrations is almost non-existent (very low), with a maximum of $0.56 \mu \mathrm{g} \cdot \mathrm{m}^{-3}$ and a minimum of $0.21 \mu \mathrm{g} \cdot \mathrm{m}^{-3}$ (3 AM). In urban areas (i.e. Abidjan), variations of diurnal concentrations of $\mathrm{BC}$ are quite significant. A maximum of 15.77 (at $7 \mathrm{AM}$ ) and a minimum of $3.85 \mu \mathrm{g} \cdot \mathrm{m}^{-3}$ (at $4 \mathrm{PM}$ ) were observed. The variability of $\mathrm{BC}$ concentrations in Abidjan is quite noticeable compared to that observed in rural areas (Lamto).

In addition, our analyses revealed that the $\mathrm{BC}$ concentrations in Lamto are lower than those of Abidjan. Indeed, at the diurnal scale, the lowest value recorded in Abidjan $\left(3.85 \mu \mathrm{g} \cdot \mathrm{m}^{-3}\right)$ is higher than the maximum value obtained in Lamto.

The ratio between the maximum values is of the order of 5.86. We also note that the emission sources in urban areas are permanently active, whereas those in rural areas, are rather linked to the seasonality of the area of interest. For instance, emission sources are more active in the dry season than in the wet season. Moreover, $\mathrm{BC}$ concentrations of Abidjan are of the same order as those obtained in Bamako (weekend) and about half of that on weekdays [45]. Some urban concentrations are however, slightly above the daily standard set by the WHO $\left(10 \mu \mathrm{g} \cdot \mathrm{m}^{-3}\right)$.

As a result, the levels of urban $\mathrm{BC}$ concentrations are alarming in contrast to rural areas, where levels remain below international daily WHO standards.

Our findings once again, underline the anthropogenic activities influence on the chemical composition of the atmosphere and air quality, particularly in large African urban centers, amplified by rapid population growth and poorly planned urbanization. Table 4 shows BC concentration for our study compared to literature for metropolises in West Africa, Asia and Europe. We have distinguished between urban and rural pollution.

Values from this study are in the same order of magnitude than those obtained in some African rural sites during intense winter biomass burning periods 
Table 4. Comparison of average $\mathrm{BC}$ concentrations measured in different regions.

\begin{tabular}{|c|c|c|c|c|}
\hline & Location & Period & $\mathrm{BC}\left(\mu \mathrm{g} \cdot \mathrm{m}^{-3}\right)$ & References \\
\hline \multirow{9}{*}{ Urban } & $\begin{array}{l}\text { Abidjan Ivory } \\
\text { Coast }\end{array}$ & Jul. 18-Jan. 20 & $5.31 \pm 2.5$ & This study \\
\hline & Dakar Senegal & Jun. 08-Jul. 09 & $5.7 \pm 1.4$ & Doumbia et al., 2012 [45] \\
\hline & Bamako. Mali & Apr. 2008 & $19.2 \pm 8.9$ & Doumbia et al., 2012 [45] \\
\hline & Cotonou. Benin & May. 2005 & $4.9 \pm 3.9$ & Doumbia et al., 2012 [45] \\
\hline & $\begin{array}{l}\text { Yaounde. } \\
\text { Cameroon }\end{array}$ & Jun.-Jul. 2004 & $4.9 \pm 3.9$ & Doumbia et al., 2012 [45] \\
\hline & Paris. France & Aug.-Oct. 97 & $10-20$ & $\begin{array}{l}\text { Ruellan and Cachier, } 2001 \\
\text { [49] }\end{array}$ \\
\hline & Singapore. Asia & Jan.-Dec. 2000 & $3-14$ & $\begin{array}{l}\text { Balasubramanian et al., } \\
2003 \text { [47] }\end{array}$ \\
\hline & Kanpur. India & Dec. 2004 & 12.3 & Tripathi et al., 2005 [48] \\
\hline & Karachi. Pakistan & Apr. 06-Apr. 07 & $2-15$ & Vincent et al., 2009 [46] \\
\hline \multirow{4}{*}{ Rural } & Lamto. Ivory Coast & Jan. 91 & $0.4-3.9$ & This study \\
\hline & Lamto. Ivory Coast & Jan. 91 & $3.4 \pm 1.1$ & Cachier et al., 1995 [50] \\
\hline & Djougou. Benin & Dec. 05-Feb. 06 & $0.4-8.2$ & Liousse et al., 2010 [51] \\
\hline & Banizoumbou & Dec. 04-Nov. 05 & $0.4-1.6$ & Liousse et al., 2010 [51] \\
\hline
\end{tabular}

such as Dakar, Cotonou, Yaounde but remains below those from Bamako according to [45]. According to study of [46], our results remain well below of thoses of Asian metropolises, in Karachi, Pakistan, [47] in Singapore, and [48] (Tripath et al.), in Kampur. In Europe, the results of [49] at Marylebone, in London and those of [50] in Paris present values largely above those from this study. It is worthy to point out the contribution of industrial pollution in the above-mentioned studies, in contrast to that of Abidjan which does not have the same industrial level as these metropolises. In rural areas, the results of our study are consistent with those of [51] in Lamto, but are above those of Banizoumou in the forest, and below that of Djougou during dry savanna [52].

This result in the rural area is expected, as Lamto is a humid savannah type ecosystem, intermediate between the forest (Banizoumou) and dry savannah (Djougou) ecosystems. Knowing that the sources of BC in rural areas are mostly related to the combustion of biomass (dry), the $\mathrm{BC}$ emissions values of Lamto are therefore between those of Banizoumou and Djougou.

\section{Conclusions}

Within the framework of the international INDAAF program (rural areas), a network of observing and monitoring atmospheric composition in tropical Africa, and the PASMU project, this work enabled us to analyze the levels of atmospheric Black Carbon concentrations in Lamto and Abidjan. 
The highest values of monthly concentrations were observed during the dry season, and the lowest during, the wet season with an average of $1.14 \pm 0.84$ $\mu \mathrm{g} \cdot \mathrm{m}^{-3}$. The seasonal average of $\mathrm{BC}$ concentrations ranges from 2.23 to 2.27 $\mu \mathrm{g} \cdot \mathrm{m}^{-3}$ and 0.28 to $0.73 \mu \mathrm{g} \cdot \mathrm{m}^{-3}$ in the dry and wet seasons respectively. The variations of $\mathrm{BC}$ concentrations show high values in the dry season than in the wet season. Our analysis shows that rural concentrations of BC in Lamto are mainly related to biomass burning sources through agricultural burning and domestic fires.

In the urban area, the study allowed us to distinguish the levels of diurnal concentrations ranging from $0.83 \mu \mathrm{g} \cdot \mathrm{m}^{-3}$ in August 2018 to $14.56 \mu \mathrm{g} \cdot \mathrm{m}^{-3}$ in December 2020) with an average of $5.31 \pm 2.5 \mu \mathrm{g} \cdot \mathrm{m}^{-3}$. Diurnal concentrations of BC on weekdays vary from $13.92 \mu \mathrm{g} \cdot \mathrm{m}^{-3}$ (7 $\mathrm{AM}$ ) to $6.87 \mu \mathrm{g} \cdot \mathrm{m}^{-3}$ at $4 \mathrm{AM}$, while on weekends they vary from $11.83 \mu \mathrm{g} \cdot \mathrm{m}^{-3}$ (8 AM) to $3.86 \mu \mathrm{g} \cdot \mathrm{m}^{-3}$ at $4 \mathrm{PM}$. Also, BC measurements were functions of days of the week, with the highest values from Monday to Fridays and the lowest ones on Sundays. Our analysis has shown that $\mathrm{BC}$ emissions are mainly related to the traffic source and domestic source (i.e. households).

As economic activities are permanent in urban areas, the sources of $\mathrm{BC}$ emissions will have a permanent character dominating largely the seasonal aspect. This is the opposite in rural areas where anthropic action is weak (little economic activity), only seasonal aspects dominate BC emission sources. Furthermore, $\mathrm{BC}$ concentration levels in urban are more alarming, in contrast to those of rural areas, which remain below international standards. The ratio between the maximum values is around 5.86. The variability of $\mathrm{BC}$ concentrations in urban areas (Abidjan) is quite significant compared to that observed in rural areas (Lamto). However, the levels of $\mathrm{BC}$ emissions in Abidjan are comparable to those of West African capitals but remain below the major metropolises of other continents.

\section{Acknowledgements}

This research was carried out within the framework of the PASMU (Air Pollution and Health in Urban Environments) project, and the long-term project INDAAF (International Network to study Deposition and Atmospheric chemistry in Africa). The authors would like to thank the leaders of these projects for the availability of data and assistance provided. We are also very grateful to $\mathrm{Ca}$ thy Liousse for her contributions

\section{Conflicts of Interest}

The authors declare no conflicts of interest regarding the publication of this paper.

\section{References}

[1] Koelmans, A.A., Jonker, T.O., Cornelissen, G., Bucheli, T.D. and Van-Noort, C.M. (2006) Black Carbon: The Reverse of Its Dark Side. Chemosphere, 63, 365-377. 
https://doi.org/10.1016/j.chemosphere.2005.08.034

[2] Stocker, T.F., Qin, D., Plattner, G.K., Tignor, P., Allen, S.K., Boschung, J., Nauels, A., et al. (2013) Climate Change 2013: The Physical Science Basis. Contribution of Working Group | to the Fifth Assessment Report of the Intergovernmental Panel on Climate Change. Cambridge University Press, Cambridge.

[3] Ostro, B., Lipsett, M. and Reynolds, P. (2010) Long-Term Exposure to Constituents of Fine Particulate Air Pollution and Mortality: Results from the California Teachers Study. Environmental Health Perspectives, 118, 363-369.

https://doi.org/10.1289/ehp.0901181

[4] Liousse, C., Penner, J.E., Chuang, C., Walton, J.J., Eddleman, H. and Cachier, H. (1996) A Global Three-Dimensional Model Study of Carbonaceous Aerosols. Journal of Geophysical Research, 105, 26871-26890. https://doi.org/10.1029/95JD03426

[5] Babu, S. and Moorthy, K.K. (2001) Anthropogenic Impact on Aerosol Black Carbon Mass Concentration at a Tropical Coastal Station: A Case Study. Current Science, 81, 1208-1214.

[6] Smith, K.R., Jerrett, M., Anderson, H.R., Burnett, R.T., Stone, V., Derwent, R., Atkinson, R.W., Cohen, A., Shonkoff, S.B., Krewski, D., Pope Iii, C.A., Thun, M.J. and Thurston, G. (2009) Public Health Benefits of Strategies to Reduce Greenhouse-Gas Emissions: Health Implications of Short-Lived Greenhouse Pollutants. The Lancet, 374, 2091-2103. https://doi.org/10.1016/S0140-6736(09)61716-5

[7] Pope, C.A. and Dockery, D.W. (2006) Health Effects of Fine Particulate Air Pollution: Lines That Connect. Journal of the Air \& Waste Management Association, 56, 709-742. https://doi.org/10.1080/10473289.2006.10464485

[8] Ramanathan, V. and Carmichael, G. (2008) Global and Regional Climate Changes Due to Black Carbon. Nature Geoscience, 1, 221-227. https://doi.org/10.1038/ngeo156

[9] Gao, X., Yu, Q., Gu, Q., Chen, Y., Ding, K. and Zhu, J. (2009) Indoor Air Pollution from Solid Biomass Fuels Combustion in Rural Agricultural Area of Tibet, China. Indoor Air, 19, 198-205. https://doi.org/10.1111/j.1600-0668.2008.00579.x

[10] Siddiqui, A.R., Lee, K., Bennett, D., Yang, X., Brown, K.H. and Bhutta, Z.A. (2009) Indoor Carbon Monoxide and $\mathrm{PM}_{2.5}$ Concentrations by Cooking Fuels in Pakistan. Indoor Air, 19, 75-82. https://doi.org/10.1111/j.1600-0668.2008.00563.x

[11] Hu, W., Downward, G.S., Reiss, B., Xu, J., Hosgood, H.D. and Zhang, L. (2014) Personal and Indoor $\mathrm{PM}_{2.5}$ Exposure from Burning Solid Fuels in Vented and Unvented Stoves in a Rural Region of China with a High Incidence of Lung Cancer. Environmental Science \& Technology, 48, 8456-8464.

https://doi.org/10.1021/es502201s

[12] Balakrishnan, K., Sambandam, S., Ghosh, S., Mukhopadhyay, K., Vaswani, M. and Arora, N.K. (2015) Household Air Pollution Exposures of Pregnant Women Receiving Advanced Combustion Cookstoves in India: Implications for Intervention. Annals of Global Health, 81, 375-385. https://doi.org/10.1016/j.aogh.2015.08.009

[13] Bartington, S.E., Bakolis, I., Devakumar, D., Kurmi, O.P., Gulliver, J. and Chaube, G. (2017) Patterns of Domestic Exposure to Carbon Monoxide and Particulate Matter in Households Using Biomass Fuel in Janakpur, Nepal. Environmental Pollution, 220, 38-45. https://doi.org/10.1016/j.envpol.2016.08.074

[14] Commodore, A.A., Hartinger, S.M., Lanata, C.F., Mäusezahl, D., Gil, A.I. and Hall, D.B. (2013) A Pilot Study Characterizing Real Time Exposures to Particulate Matter and Carbon Monoxide from Cookstove Related Woodsmoke in Rural Peru. Atmospheric Environment, 79, 380-384. 
https://doi.org/10.1016/j.atmosenv.2013.06.047

[15] Fitzgerald, C., Aguilar-Villalobos, M., Eppler, A.R., Dorner, S.C., Rathbun, S.L. and Naeher, L.P. (2012) Testing the Effectiveness of Two Improved Cookstove Interventions in the Santiago de Chuco Province of Peru. Science of the Total Environment, 420, 54-64. https://doi.org/10.1016/j.scitotenv.2011.10.059

[16] Riojas-Rodriguez, H., Schilmann, A., Marron-Mares, A.T., Masera, O., Li, Z. and Ro Manoff, L. (2011) Impact of the Improved Patsari Biomass Stove on Urinary Polycyclic Aromatic Hydrocarbon Biomarkers and Carbon Monoxide Exposures in Rural Mexican Women. Environmental Health Perspectives, 119, 1301-1307. https://doi.org/10.1289/ehp.1002927

[17] Ochieng, C.A., Vardoulakis, S. and Tonne, C. (2013) Are Rocket Mud Stoves Associated with Lower Indoor Carbon Monoxide and Personal Exposure in Rural Kenya? Indoor Air, 23, 14-24. https://doi.org/10.1111/j.1600-0668.2012.00786.x

[18] Pennise, D., Brant, S., Agbeve, S.M., Quaye, W., Mengesha, F. and Tadele, W. (2009) Indoor Air Quality Impacts of an Improved Wood Stove in Ghana and an Ethanol Stove in Ethiopia. Energy for Sustainable Development 13, 71-76. https://doi.org/10.1016/j.esd.2009.04.003

[19] Yoboué, V., Galy-Lacaux, C., Lacaux, J.P. and Silué, S. (2005) Rainwater Chemistry and Wet Deposition over the Wet Savanna Ecosystem of Lamto (Côte d'Ivoire). Journal of Atmospheric Chemistry, 52, 117-141. https://doi.org/10.1007/s10874-005-0281-Z

[20] Galy-Lacaux, C. and Delon, C. (2014) Nitrogen Emission and Deposition Budget in Westand Central Africa. Environmental Research Letters, 9, Article ID: 125002. https://doi.org/10.1088/1748-9326/9/12/125002

[21] Adon, M., Galy-Lacaux, C., Yoboué, V., Delon, C., Lacaux, J.P., Castera, P. and Gardrat, E. (2010) Long Term Measurements of Sulfur Dioxide, Nitrogen Dioxide, Ammonia, Nitric Acid and Ozone in Africa Using Passive Samplers. Atmospheric Chemistry and Physics, 10, 4407-4461. https://doi.org/10.5194/acpd-10-4407-2010

[22] Adon, M., Delon, C., Yoboué, V., Solmon, F. and Kaptue Tchuente, A.T. (2013) Dry Deposition of Nitrogen Compounds $\left(\mathrm{NO}_{2}, \mathrm{HNO}_{3}, \mathrm{NH}_{3}\right)$, Sulfur Dioxide and Ozone in West and Central African Ecosystems Using the Inferential Method. Atmospheric Chemistry and Physics, 13, 11351-11374. https://doi.org/10.5194/acp-13-11351-2013

[23] Adon, M., Yoboue, V., Galy-Lacaux, C., Liousse, C., Diop, B., Doumbia, E.H.T., Gardrat, E., Ndiaye, S.A. and Jarnot, C. (2016) Measurements of $\mathrm{NO}_{2}, \mathrm{SO}_{2}, \mathrm{NH}_{3}$, $\mathrm{HNO}_{3}$ and $\mathrm{O}_{3}$ in West African Urban. Atmospheric Environment, 135, 31-40. https://doi.org/10.1016/j.atmosenv.2016.03.050

[24] Bahino, J., Yoboué, V., Galy-Lacaux, C., Adon, M., Akpo, A., Keita, S., et al. (2018) A Pilot of Gaseous Pollutants' Measurement $\left(\mathrm{NO}_{2}, \mathrm{SO}_{2}, \mathrm{NH}_{3}, \mathrm{HNO}_{3}\right.$ and $\left.\mathrm{O}_{3}\right)$ in Abidjan, Côte d'Ivoire: Contribution to an Overview of Gaseous Pollution in African Cities. Atmospheric Chemistry and Physics, 18, 5173-5198. https://doi.org/10.5194/acp-18-5173-2018

[25] Djossou, J., Léon, J.F., Akpo, A., Liousse, C., Yoboué, V., Bedou, M., Bodjrenou, M., Chiron, C., et al. (2018) Mass Concentration, Optical Depth and Carbon Composition of Particulate Matter in the Major Southern West African Cities of Cotonou (Benin) and Abidjan (Côte d'Ivoire). Atmospheric Chemistry and Physics, 18, 6275-6291. https://doi.org/10.5194/acp-18-6275-2018

[26] Adon, A.J., Liousse, C., Doumbia, T., Baeza-Squiban, A., Cachier, H., Léon, J.F., et al. (2020) Physico-Chemical Characterization of Urban Aerosols from Specific 
Combustion Sources in West Africa at Abidjan in Côte d'Ivoire and Cotonou in Benin in the Frame of the DACCIWA Program. Atmospheric Chemistry and Physics, 20, 5327-5354. https://doi.org/10.5194/acp-20-5327-2020

[27] Arbeille, J. (1986) Recherches biologiques et écologiques sur les blattes de la région de Lamto (Côte d'Ivoire). Thèse de Doctorat, Université Paris 6, Paris.

[28] Olahan, A. (2010) Agriculture urbaine et stratégies de survie des ménages pauvres dans le complexe spatial du district d'Abidjan. VertigO, 10, 24.

[29] Longhurst, A.R. (1962) A Review of the Oceanography of the Gulf of Guinea. Bulletin of IFAN, 24, 633-663.

[30] Morliere, A. and Robert, J.P. (1972) Etude hydrologique du plateau continental ivoirien. Documents Scientifiques-CRO, $30 \mathrm{p}$.

[31] Hansen, A.D., Rosen, H. and Novakov, T. (1984) The Aethalometer: An Instrument for the Real Time Measurement of Optical Absorption by Particles. Science of the Total Environment, 36, 191-196. https://doi.org/10.1016/0048-9697(84)90265-1

[32] Drinovec, L., Monik, G., Zotter, P., Prévôt, A.H., Ruckstuhl, C., Coz, E., et al. (2015) The "Dual-Spot" Aethalometer: An Improved Measurement of Aerosol Black Carbon with Real-Time Loading Compensation. Atmospheric Measurement Techniques, 8, 1965-1979. https://doi.org/10.5194/amt-8-1965-2015

[33] Hansen, J., Nazarenko, L., Ruedy, R., Sato, M., Willis, J., Del Genio, D., et al. (2005) Earth's Energy Imbalance: Confirmation and Implications. Science, 308, 1431-1435. https://doi.org/10.1126/science.1110252

[34] Virkkula, A., Mekele, T., Hillamo, R., Yli-Tuomi, T., Hirsikko, A., Hemeri, K. and Koponen, I. (2007) A Simple Procedure for Correcting Loading Effects of Aethalometer Data. Journal of the Air \& Waste Management Association, 57, 1214-1222. https://doi.org/10.3155/1047-3289.57.10.1214

[35] Weingartner, E., Saathoff, H., Schnaiter, M., Streit, N., Bitnar, B. and Baltens-Perger U. (2003) Absorption of Light by Soot Particles: Determination of the Absorption Coefficient by Means of Aethalometers. Journal of Aerosol Science, 34, 1445-1463. https://doi.org/10.1016/S0021-8502(03)00359-8

[36] Jeong, C.H., Hopke, P.K., Kim, E. and Lee, D.W. (2004) The Comparison between Thermal-Optical Transmittance Elemental Carbon and Aethalometer Black Carbon Measured at Multiple Monitoring Sites. Atmospheric Environment, 38, 5193-5204. https://doi.org/10.1016/j.atmosenv.2004.02.065

[37] Wang, Y.G., Hopke, P.K., Rattigan, O.V. and Zhu, Y. (2011) Characterization of Ambient Black Carbon and Wood Burning Particles in Two Urban Areas. Journal of Environmental Monitoring, 13, 1919-1926. https://doi.org/10.1039/c1em10117j

[38] Srivastava, A., Singh, S., Tiwari, S. and Bisht, D. (2012) Contribution of Anthropogenic Aerosols in Direct Radiative Forcing and Atmospheric Heating Rate over Delhi in the Indo-Gangetic Basin. Environmental Science and Pollution Research, 19, 1144-1158. https://doi.org/10.1007/s11356-011-0633-y

[39] Tiwari, V.M., Wahr, J. and Swenson, S. (2009) Dwindling Groundwater Resources in Northern India, from Satellite Gravity Observations. Geophysical Research Letters, 36, 184-201. https://doi.org/10.1029/2009GL039401

[40] Collaud, M., Weingartner, E., Apituley, A., Ceburnis, D., Fierz-Schmidhauser, R., Flentje, H., et al. (2010) Minimizing Light Absorption Measurement Artifacts of the Aethalometer: Evaluation of Five Correction Algorithms. Atmospheric Measurement Techniques, 3, 457-474. https://doi.org/10.5194/amt-3-457-2010

[41] Sigha-Nkamdjou, L., Galy-Lacaux, C., Pont, V., Richard, S., Sighoumnou, D. and 
Lacaux, J.P. (2003) Rainwater Chemistry and Wet Deposition over the Equatorial Forested Ecosystem of Zoétélé (Cameroon). Journal of Atmospheric Chemistry, 46, 173-198. https://doi.org/10.1023/A:1026057413640

[42] Abbadie, L., Gignoux, J., Lepage, M. and Le Roux, X. (2006) Environmental Constraints on Living Organisms. In: Abbadie, L., Gignoux, J., Le Roux, X. and Lepage M., Eds., Lamto. Ecological Studies (Analysis and Synthesis), Springer, New York, 45-61. https://doi.org/10.1007/0-387-33857-8_4

[43] Ouafo-Leumbe, M.R., Galy-Lacaux, C., Liousse, C., et al. (2018) Chemical Composition and Sources of Atmospheric Aerosols at Djougou (Benin). Meteorol Atmos Phys, 130, 591-609. https://doi.org/10.1007/s00703-017-0538-5

[44] Liousse, C. and Cachier, H. (1992) Measurement of Black Carbon Aerosols in the Atmosphere of Two Different Source Regions: Real-Time Data for the Paris Region and a Savanna Site of the Ivory Coast. Environmental Technology, 13, 959-967. https://doi.org/10.1080/09593339209385231

[45] Doumbia, E.H.T., Liousse, C., Galy-Lacaux, C., Ndiaye, S.A., Diop, B., Ouafo, M., Assamoi, E.M., Gardrat, E., Castera, P., Rosset, R., Akpo, A. and Sigha, L. (2012) Real Time Black Carbon Measurements in West and Central Africa Urban Sites. Atmospheric Environment, 54, 529-537.

https://doi.org/10.1016/j.atmosenv.2012.02.005

[46] Vincent, A., Dutkiewicz Alvi, S., Ghauri, B.M., Choudhary, M.I. and Husain, L. (2009) Black Carbon Aerosols in Urban Air in South Asia. Atmospheric Environment, 43, 1737-1744. https://doi.org/10.1016/j.atmosenv.2008.12.043

[47] Balasubramanian, R., Qian, W.B., Dccesari, S., Facchini, M.C. and Fuzzi, S. (2003) Comprehension Characterization of $\mathrm{PM}_{2.5}$ Aerosols in Singapore. Journal of Geophysical Research: Atmospheres, 108, Article ID: 4523.

https://doi.org/10.1029/2002JD002517

[48] Tripathi, S.N., Dey, S., Tare, V. and Satheesh, S.K. (2005) Aerosol Black Carbon Radiative Forcing at an Industrial City in Northern India. Geophysical Research Letters, 32, No. 8. https://doi.org/10.1029/2005GL022515

[49] Green, D., Alexander, J. and Fuller, G. (2007) Marylebone Road Aethalometer Trial Report. Environmental Research Group, King's College, London, 41 p.

[50] Ruellan, S. and Cachier, H. (2001) Characterization of Fresh Particulate Vehicular Exhausts Near a Paris High Flow Road. Atmospheric Environment, 35, 453-468. https://doi.org/10.1016/S1352-2310(00)00110-2

[51] Cachier, H., Liousse, C. and Buat-Menard, P. (1995) Particulate Content of Savanna Fire Emissions. Journal of Atmospheric Chemistry, 22, 123-148. https://doi.org/10.1007/BF00708185

[52] Liousse, C., Guillaume, B., Grégoire, J.M., Mallet, M., Galy, C., Pont, V., et al. (2010) Western African Aerosols Modelling with Updated Biomass Burning Emission Inventories in the Frame of the AMMA-IDAF Program. Atmospheric Chemistry and Physics Discussions, 10, 7347-7382. https://doi.org/10.5194/acpd-10-7347-2010 